\title{
Future Teachers' Opinions on Preparation and Use of Interactive Materials in Teaching
}

\author{
https://doi.org/10.3991/ijet.v15i23.18805 \\ Aigul Kassabolat $\left.{ }^{(}\right)$ \\ L.N. Gumilyov Eurasian National University, Nur-Sultan, Kazakhstan \\ kasabolata@gmail.com \\ Shynar Kadirsizova \\ Kazakh Humanitarian Law Innovation University, Semey, Kazakhstan \\ Makhabbat Kozybayeva \\ Ch.Ch. Valikhanov Institute of History and Ethnology, Almaty, Kazakhstan \\ Kamaryash Kalkeyeva \\ L.N. Gumilyov Eurasian National University, Nur-Sultan, Kazakhstan \\ Meiramgul Zhorokpayeva \\ Semey Medical University, Semey, Kazakhstan \\ Yerimova Aknur \\ Turkish University, Turkestan, Kazakhstan
}

\begin{abstract}
This study aims to determine the opinions of students in the primary education department about the preparation and use of materials with the teaching practice in Instructional Technologies and Material Design (TTMD) course. This study is a descriptive study based on qualitative data. The sample of the research consists of 49 students from the primary education department who took TTMD course at Almaty University in the 2018-2019 academic year. The data of the research were collected by structured interview form. According to the results, it has been revealed that primary school teacher candidates emphasized the importance on preparing and using materials based on their answers regarding the use and preparation of materials in teaching. When the opinions of primary school teacher candidates about the criteria that they value in preparing and using materials were examined, they emphasized the criteria such as suitability for the student level, fitness for the purpose, being clear and easy to understand. Moreover, the results showed that future primary school teachers have difficulty in finding materials and tools suitable for this purpose.
\end{abstract}

Keywords - Future teachers, primary education, educational materials 


\section{Introduction}

Education is generally a process of behaviour change in the individual. Changes that may occur in the behaviour of individuals during teaching process are expected to be in the desired direction. In this sense, Ozkan [17] explained education as the process of generating desired deliberate change in individuals' behaviour. In our rapidly changing and developing world, individuals are not expected to receive and memorize information from a single source. On the contrary, it is aimed to train individuals who know the ways to access information, can use them and create solutions using the information they face. The use of instructional materials prepared in accordance with instructional technology principles is important for individuals to acquire these features, to design effective and interactive learning environments [10]. Until the 1960s, while tools and equipment were seen as educational aids that support education and their use was abandoned to the special wishes and interests of teachers, today it has started to be accepted as an indispensable element of learning-teaching systems [1].

In order to use teaching materials in various and sufficient levels, both knowing them well and knowing their features and planning, learning principles, developmental psychology is crucial. It is especially important to know what kind of materials can be used for which type of teaching objectives. As it is known, there are some factors that affect the choice of teaching materials. Teaching objectives, teaching methods to be used, student characteristics, environment characteristics, attitudes of teachers, time and cost are the main ones. With the developing and changing conditions, teachers and those who need other presentation technologies can easily find the teaching tools and materials they need in the market. However, it can sometimes be difficult, time consuming and expensive to achieve. In these cases, teachers need some tools and equipment they need and prepare the materials themselves or have them prepared by guiding the students $[24,14]$.

According to Cetinkaya [4], the use of materials in education plays an important role in the success of the program by preparing an effective educational environment and enabling students to reach the foreseen goals more easily, and this is important for effective education. The use of materials in education facilitates perception and learning. It attracts attention, arouses interest and brings vitality to the class. In learning, it shortens time, reinforces knowledge and helps persistence. It makes it easier to remember learned information. According to the theory of processing information, there are three types of memory. These are affective memory, short-term memory, long-term memory [23]. Considering that the information is stored verbally and visually in long-term memory, the information presented both verbally and visually will be more likely to be remembered. It has been found that concrete words are remembered more than abstract words and pictures are more remembered than words [20]. Instructional material provides the presentation of consistent information at different times and provides the opportunity to use it again and again. It enables students to participate in the subject, evokes the desire to read and research. It carries the events, facts and assets that cannot be brought to the classroom with their real faces [20]. 
Teaching materials have an important place in effective learning and teaching, because teaching materials provide students with more permanent learning, motivate learning by drawing their attention, objectify abstract concepts and simplify unclear concepts [13]. Teaching materials both help the application of teaching programs, keep students away from boredom by making lesson entertaining, shorten learning period and increase the efficiency of lesson [11]. Learning how to prepare and use teaching materials that provide taking out features such as sharing information during education, accessing information, objectifying abstract demonstrations, communication within class, motivation and creativity [12], by teachers/teacher candidates in teacher training programmes is an important efficiency. That is why a lecture that gains this efficiency in a teacher training programme seems to be important. With this lecture it is aimed to gain sufficiency of preparing material and make them ready and willing to use material when they become teacher. Teacher candidates gain sufficiency of presenting their knowledge more effective, attractive and efficiency after taking TTMD lesson [9,22].

The first studies on technology, mostly educational software and similar technologies on student success and motivation focused on its effects. Due to the ease and increase in computer and internet access, researchers have tendency to examine the role of technology in educational environments in terms of its impact on teachers and the educational process. Therefore, in those studies, technology was considered as an integral part of the teaching environment and a tool that could be used for different purposes rather than a tool in which teaching content was transferred [2]. When the literature on teaching technologies was examined, it was seen that the studies were carried out by using different research methods in different educational environments. Some meta-analysis studies conducted in previous years systematically examined the effects of technology on student achievement [26]. For example, several metaanalysis studies were conducted to investigate the effect of computer assisted education on student achievement [21,7].

Considering the importance of using technology and instructional materials in education, it is important to notice that "Instructional Technologies and Material Design" lecture education faculties should draw more attention. The attitudes and opinions of future primary school teachers towards this lesson is rather important. In this study, it was aimed to determine the opinions of primary school teacher candidates regarding the preparation and use of materials within the scope of the Instructional Technologies and Material Design course. For this purpose, the answers to these questions were sought:

1. In what ways do you find it important to prepare and use materials for education?

2. What criteria do you consider when preparing the materials?

3 . What problems do you encounter during the preparation of the materials?

4. When you become a teacher, do you find the materials you prepared effective for teaching? 


\section{$2 \quad$ Method}

\section{$2.1 \quad$ Research model}

This study is a descriptive study based on qualitative data. Qualitative studies aim to explain and understand the current situation in depth. Qualitative research is more concerned with the process than the available data or results. For this reason, meanings are more important than the results obtained in qualitative research [27].

\section{$2.2 \quad$ Study group}

A total number of 49 students studying in the department of Primary Education at Almaty University who had previously taken or were taking this lecture in the second term of 2018-2019 academic year constituted the study group of this study. Table 1 shows the demographic characteristics of the participants of the study including gender and age. As it can be seen from the table, 29 participants were female and 20 were male. In addition, 12 participants were between the ages of 17 and 20, 18 of them 21 and 22 and 19 of them were 23 and over.

Table 1. Demographic characteristics of the participants of the study

\begin{tabular}{|l|l|l|}
\hline \multicolumn{1}{|c|}{ Variable } & \multicolumn{1}{|c|}{ Level } & N \\
\hline \multirow{3}{*}{ Gender } & Female & 29 \\
\cline { 2 - 3 } & Male & 20 \\
\hline \multirow{3}{*}{ Age } & Total & 49 \\
\hline \multirow{2}{*}{} & $17-20$ & 12 \\
\cline { 2 - 3 } & $21-22$ & 18 \\
\cline { 2 - 3 } & 23 and over & 19 \\
\hline & Total & 49 \\
\hline
\end{tabular}

\subsection{Data collection tool}

First of all, after the interview questions were prepared by the researchers, the opinions of two experts in their field were taken to ensure the validity of the data collection tool and the questions were finalized. Two pilot interviews were conducted to test the interview questions. Pilot interviews were not included in the study. After the interview questions were determined, questions were asked to all participants in the same order, and explanations were made to make it easier for the participant to understand and answer the question by paying attention not to be guiding when needed. 4 questions were asked to the students in the research.

\subsection{Data collection}

Data were collected when both the researchers and the students were available. The researchers first explained the purpose of the study, explained that the interviews with 
the participants would be recorded on a tape recorder and that the recordings would not be listened to by anyone other than the researchers. The interviews were carried out in the seminar hall of Almaty University.

\subsection{Data analysis}

The data were analysed inductively which is one of the qualitative analysis techniques. Inductive analysis is carried out to provide understanding of complex data through summary themes or categories developed from raw data [6].

\section{$3 \quad$ Results}

\subsection{Results on future teachers' opinions on the importance of preparing and using materials for education}

The findings that were obtained from the opinions of future primary school teachers regarding important to prepare and use materials for education were given in Table 2. As can be seen in the table, participants stated their opinions regarding importance of preparing and using materials in education mostly as providing permanence in learning.

Table 2. Opinions on the importance of preparing and using materials for education

\begin{tabular}{|l|c|}
\hline \multicolumn{1}{|c|}{ Opinion } & F \\
\hline Permanence in Learning & 25 \\
\hline Consolidation & 15 \\
\hline Participation to Lesson & 6 \\
\hline Easy Learning & 2 \\
\hline Motivation & 1 \\
\hline
\end{tabular}

Sample statements are as follows;

P1: "Our main purpose is to convey information to our students. We need to provide the best training in this. The materials we will use during the lesson are very important. The more we choose the right material, the more we attract students, we keep the information in mind. Briefly, materials are important in terms of providing permanence in learning."

P5: "Instructional design materials should be easy and understandable. Its effect on learning is enormous."

\subsection{Results on future teachers' opinions on criteria they consider when preparing materials}

The findings that were obtained from the opinions of future primary teachers regarding criterions that they consider in preparation and using of materials, were given in Table 3. As it is seen in Table 3, the participants stated their opinions 
regarding importance of preparing and using materials in education mostly as compliance with the content of the course. 2 of the participants expressed the importance of preparing and using materials in terms of suitability of finance.

Table 3. Opinions on criteria they consider when preparing materials

\begin{tabular}{|l|c|}
\hline \multicolumn{1}{|c|}{ Opinions } & F \\
\hline Compliance with the content of the course & 18 \\
\hline Compliance with students & 7 \\
\hline Reusability & 7 \\
\hline Intelligibility & 5 \\
\hline Easy & 5 \\
\hline Durability & 4 \\
\hline Suitability in terms of finance & 2 \\
\hline
\end{tabular}

Sample statements are as follows:

P20: "When I prepare the material, I question what the purpose is. Selection of material for my purpose is the most important rule."

P33: "In order to provide effective learning, the material to be taken to the class should attract the attention of the student. A material that attracts students' attention provides learning retention. Therefore, while preparing the material, I note that the materials have the feature of attracting students' attention.

\subsection{Results on future teachers' opinions on the problems they encounter during the preparation of the materials}

The findings that were obtained from the opinions of future primary school teachers regarding problems that they encounter during preparation of materials were shown in Table 4. Results showed that participants mostly stated their views on the importance of preparing and using materials in education as a difficulty in finding materials. Another view expressed by students were having difficulty as they were financially costly.

Table 4. Encounter during the preparation of the materials

\begin{tabular}{|l|c|}
\hline \multicolumn{1}{|c|}{ Opinions } & F \\
\hline Difficulty in finding material & 14 \\
\hline Appropriate material design process & 10 \\
\hline Financially costly & 10 \\
\hline Taking too much time & 8 \\
\hline Disagreement within group & 2 \\
\hline
\end{tabular}

Sample statements are as follows:

P17: "I have difficulty in designing materials, when designing suitable materials for the materials I have. If I have a lot of materials, I can design much better teaching materials." 
P28: "I have financial difficulties. I am thinking about what I can do with affordable materials, as I will buy them to create materials."

\subsection{Results on future teachers' opinions whether they will use the materials they prepared in their professional life}

The findings on the opinions of participants whether they would use the materials they prepared in their professional life were given in Table 5.

Table 5. The condition of using materials that Primary school teachers candidates prepared when they become a teacher

\begin{tabular}{|l|c|}
\hline \multicolumn{1}{|c|}{ Opinions } & F \\
\hline Difficulty in finding material & 14 \\
\hline Appropriate material design process & 10 \\
\hline Financially costly & 10 \\
\hline Taking too much time & 8 \\
\hline Disagreement within group & 2 \\
\hline
\end{tabular}

According to the results regarding the opinions of participants regarding the use of materials that they prepared during their education, 35 students gave the answer "I use those materials" and 14 of them gave the answer "I do not use those materials". The participants who gave the answer "Yes" expressed that they used them because they made a great effort and the participants responded as "No" expressed that the materials that they previously prepared were insufficient for education.

Sample statements are as follows:

P40: "I worked for days while preparing the materials, got feedback from my teacher and it was very nice. So, I will use it when I become a teacher".

P43: "No, because the materials I have used are insufficient and I prepared the lesson to pass. I will never use this material when I become a teacher because it will be insufficient and very simple for the training I will teach."

\section{Discussion and Conclusion}

Instructional Technologies and Material Design (TTMD) course, which is one of the compulsory courses that students at faculty of education have to take, aims to provide students with the knowledge and skills related to the preparation and use of materials. The evaluation of the TTMD course is important in terms of the effectiveness of the course, which allows students to attract their attention, motivate their learning, keep their attention alive, make abstract concepts more concrete, and facilitate the regular acquisition of information. learning and teaching process. Teaching materials help students acquire more memorable information. Teaching materials have a significant impact on providing a more permanent and simple learning method at every stage of education. 
Results of the present study showed that future primary school teachers will use materials in order to be permanent in learning, to be durable, to facilitate learning, to reinforce and to motivate students. Participants stated their opinions regarding importance of preparing and using materials in education mostly as providing permanence in learning. These results obtained from the findings are consistent with the literature. Instructional design is important in terms of being permanent in learning and increase motivation $[15,16,26,3]$.

Furthermore, participants stated that the most important criteria for preparing and using materials are fitness for purpose, fitness for students' level, simplicity and understandability. When the literature was analysed, it was observed that the most important criteria in the preparation and use of materials were suitability for the objectives in the education programs. Reigeluth, Beatty and Myers [18] concluded that the suitability of instructional material designs for the purpose was very important. It was also revealed that participants had difficulties in choosing suitable materials, they had difficulties in finding equipment while preparing materials as they were financially costly. When the studies conducted were examined, the financial problems in terms of suitability of the materials for instructional designs could be generalized $[19,5,8]$.

According to the results, future primary school teachers stated that they would use their materials they prepared in the lecture. They stated that they could develop the material, they were durable, educational, informative and suitable for the level of students. Based on these findings, it could be said that primary school teacher candidates prepare their materials in accordance with the principles of preparing materials. The minority of participants stated that they would not use the materials they prepared as they were inadequate and durable for education.

In line with all the obtained results, instructional technology material designs are very important in the education of prospective teachers. The gains they learned in this lesson are important. It can be concluded that these courses should be increased when students have difficulty in preparing materials and have difficulty in determining appropriate materials. Therefore, teacher candidates should be trained better in material planning, preparation, application and evaluation. In addition, it may be recommended to conduct further research on the effectiveness of "Instructional Technologies and Material Design" course and to examine different dimensions of the course such as the use of technology as well as the material preparation dimension.

\section{$5 \quad$ References}

[1] Alkan, C., Deryakulu, D., \& Simsek, N. (1995). Egitimde yeni teknolojiler: Egitim teknolojisine giris. Ankara: Onder Matbaacilik.

[2] Cabrera-Solano, P., Quinonez-Beltran, A., Gonzalez-Torres, P., Ochoa-Cueva, C., \& Castillo-Cuesta, L. (2020). Enhancing EFL Students' Active Learning by Using 'Formative'on Mobile Devices. International Journal of Emerging Technologies in Learning (iJET), 15(13): 252-263. https://doi.org/10.3991/ijet.v15i13.13975 
[3] Buldu, D., \& Armagan, F. (2019). Determination of the opinions of prospective science teachers about the planned trip to the sugar factory. International Journal of Innovative Research in Education, 6(2): 21-39. https://doi.org/10.18844/ijire.v6i2.4474

[4] Madi, N. A. M., Albakry, N. S., \& Ibrahim, N. (2020). AR Mobile Application in Learning Hajj for Children in Malaysia: A Preliminary Study. International Journal of Interactive Mobile Technologies, 14(16). https://doi.org/10.3991/ijim.v14i16.12807

[5] Constantinescu, M. (2017). Valuing the educational changes in the Romanian educational system. Global Journal of Psychology Research: New Trends and Issues, 7(2): 86-89. https://doi.org/10.18844/gjpr.v7i2.2574

[6] Creswell, J. W., \& Creswell, J. D. (2005). Mixed method research: Developments, debates, and dilemmas. In R. A. Swanson \& E. F. Holton III (Eds.), Research in organizations: Foundations and methods of inquiry (pp. 315-326). San Francisco, CA: Berrett-Koehler.

[7] Dincer, S. (2015). Effects of computer-assisted learning on students' achievements in Turkey: A Meta-Analysis. Journal of Turkish Science Education, 12(1): 99-118. https:// doi.org/10.12973/tused.10136a

González, L. F. M., \& Quiroz, V. G. (2019). Instructional design in online education: A systemic approach. European Journal of Education, 2(3): 64-73. http://dx.doi.org/10.26417 lejed.v2i3.p64-73

[8] Gunduz, S., \& Odabasi, F. (2004). The importance of lesson of Education Technologies and developing materials in education of teacher candidates in Information Era. The Turkish Online Journal of Educational Technology, 3(1): 43-48.

[9] Gulbahar, Y., \& Alper, A. (2009). Ogretim teknolojileri alaninda yapilan arastirmalar konusunda bir icerik analizi. Ankara Universitesi Egitim Bilimleri Fakultesi Dergisi, 42(2): 93-112. https://doi.org/10.17679/inuefd.642759

[10] Kazu, H., \& Yesilyurt, E. (2008). Ogretmenlerin ogretim arac-gereclerini kullanim amaclari. Firat Universitesi Sosyal Bilimler Dergisi, 18(2): 175-188. https://doi.org/10. 18026/cbayarsos.525652

[11] Harunasari, S. Y., \& Halim, N. (2019). Digital Backchannel: Promoting Students' Engagement in EFL Large Class. International Journal of Emerging Technologies in Learning (iJET), 14(07): 163-178. https://doi.org/10.3991/ijet.v14i07.9128

[12] Kukey, E., Gunes, H., \& Genc, Z. (2019). Experiences of classroom teachers on the use of hands-on material and educational software in math education. World Journal on Educational Technology: Current Issues, 11(1): 74-86. https://doi.org/10.18844/wjet.v11i1. $\underline{4010}$

[13] Kurniaman, O., \& Zufriady, Z. (2019). The effectiveness of teaching materials for graphic organizers in reading in elementary school students. Journal of Educational Sciences, 3(1), 48-62. https://jes.ejournal.unri.ac.id/index.php/JES

[14] McEneaney, J. E. (2016). Simulation-based evaluation of learning sequences for instructional technologies. Instructional Science, 44(1): 87-106. https://doi.org/10.1007/s1 1251-016-9369-x

[15] Orhan-Karsak, H. G. (2017). Investigation of teacher candidates' opinions about instructional technologies and material usage. Journal of Education and Training Studies, 5(5): 204-216. https://doi.org/10.11114/jets.v5i5.2286

Ozkan, R. (2017). Egitim bilimine giris. Ankara: Pegem Akademi. https://doi.org/10. $\underline{11114 / \text { jets.v5i5.2286 }}$

[16] Reigeluth, C. M., Beatty, B. J., \& Myers, R. D. (Eds.). (2016). Instructional-design theories and models, Volume IV: The learner-centered paradigm of education. UK: Routledge. https://doi.org/10.1007/s11528-017-0193-1 
[17] Roscoe, R. D., Craig, S. D., \& Douglas, I. (Eds.). (2017). End-user considerations in educational technology design. IGI Global.

[18] Sagiroglu, N., \& Uzunboylu, H. (2018). Analysis of the published articles related to autism in Turkey: A model proposal for students. Journal of Education and Special Education Technology, 4(1): 14-23. https://un-pub.eu/ojs/index.php/JESET/article/view/4105/4033

[19] Schroeder, C. M., Scott, T. P., Tolson, H., Huang, T. Y., \& Lee, Y. H. (2007). A metaanalysis of national research: Effects of teaching strategies on student achievement in science in the United States. Journal of Research in Science Teaching: The Official Journal of the National Association for Research in Science Teaching, 44(10):1436-1460. https ://doi.org/10.1002/tea.20212

[20] Seckinli, M., \& Arslan, M. (2019). Comparison of design and application criteria for various methods used in reinforced concrete beam strengthening. Global Journal of Arts Education, 9(1): 35-42. https://doi.org/10.18844/gjae.v9i2.4028

[21] Tobias, A. (2020). A unified epistemological theory of information processing. Theory and Decision, 1-21.

[22] Touli, E. H., Talbi, M., \& Radid, M. (2018). The evaluation in the physical sciences in the Moroccan secondary school curriculum: the case of experimental skills. Contemporary Educational Researches Journal, 8(2): 66-71. https://doi.org/10.18844/cerj.v8i2.846

[23] Waxman, H. C., Lin, M. F., \& Michko, G. (2003). A meta-analysis of the effectiveness of teaching and learning with technology on student outcomes. UK: Learning Point Associates.

[24] Suartama, I. K., Setyosari, P., Sulthoni, S., \& Ulfa, S. (2019). Development of an instructional design model for mobile blended learning in higher education. International Journal of Emerging Technologies in Learning (iJET), 14(16): 4-22. https://doi.org/10.39 91/ijet.v14i16.10633

[25] Yildirim, A., \& Simsek, H. (2008). Nitel arastirma yontemleri [Qualitative research methods]. Ankara: Seckin Yayincilik

\section{Authors}

Aigul Kassabolat, $\mathrm{PhD}$ doctoral student, L.N. Gumilyov Eurasian National University, Nur-Sultan, Kazakhstan. kasabolata@gmail.com

Shynar Kadirsizova, PhD doctoral student, Kazakh Humanitarian Law Innovation University of Semey, Semey, Kazakhstan. shnar_83kz@mail.ru

Makhabbat Kozybayeva, $\mathrm{PhD}$, Scientific Secretary of the Ch.Ch. Ualikhanov Institute of History and Ethnology, Almaty, Kazakhstan. koz.mahabbat_85@mail.ru

Kamaryash Kalkeyeva, Doctor of Pedagogical Sciences, Professor, L.N. Gumilyov Eurasian National University Department of social pedagogics and selfknowledge. Nur-Sultan, Kazakhstan. kalkeevatamara@mail.ru

Meiramgul Zhorokpayeva, Candidate of pedagogical science, Semey medical university, Semey, Kazakhstan E-mail: miramgul.zhorakpaeva@mail.ru

Yerimova Aknur, Master degree, Senior Lecturer, Khoja Akhmet Yassawi International Kazak-Turkish University Department of laboratory disciplines, Kazakhstan, Turkistan E-mail: $\underline{\text { Aknur.erimova@ayu.edu.kz }}$

Article submitted 2020-09-09. Resubmitted 2020-10-08. Final acceptance 2020-10-08. Final version published as submitted by the authors. 